\title{
Powder X-ray Diffraction and Particle Size Analysis of the Consciousness Energy Healing Treated Vanadium Pentoxide $\left(\mathrm{V}_{2} \mathrm{O}_{5}\right)$
}

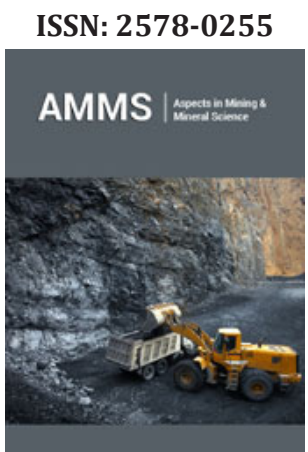

*Corresponding author: Snehasis Jana, Trivedi Science Research Laboratory Pvt. Ltd., Thane (W), Maharashtra, India

\section{Submission: 倫 May 29, 2019}

Published: 祭June 07, 2019

Volume 3 - Issue 1

How to cite this article: Nayak $G$ Trivedi MK, Branton A, Trivedi D, Jana S Powder X-ray Diffraction and Particle Size Analysis of the Consciousness Energy Healing Treated Vanadium Pentoxide $\left(\mathrm{V}_{2} \mathrm{O}_{5}\right)$. Aspects Min Miner Sci.3(1). AMMS.000553.2019.

DOI: 10.31031/AMMS.2019.03.000553

Copyright@ Gopal Nayak, This article is distributed under the terms of the Creative Commons Attribution 4.0 International License, which permits unrestricted use and redistribution provided that the original author and source are credited.

\author{
Nayak $\mathrm{G}^{1}$, Trivedi $\mathrm{MK}^{1}$, Branton $\mathrm{A}^{1}$, Trivedi $\mathrm{D}^{1}$, Jana $\mathrm{S}^{2 *}$ \\ ${ }^{1}$ Trivedi Global Inc. Henderson, USA \\ ${ }^{2}$ Trivedi Science Research Laboratory Pvt Ltd., Thane (W), India
}

\begin{abstract}
Vanadium pentoxide $\left(\mathrm{V}_{2} \mathrm{O}_{5}\right)$ is an inorganic compound, which is used for the chemical synthesis and other industrial applications. In this study, the impact of the Trivedi Effect ${ }^{\circledR}$-Consciousness Energy Healing Treatment on the physicochemical properties of $\mathrm{V}_{2} \mathrm{O}_{5}$ powder was evaluated using powder X-ray diffraction and particle size distribution analytical techniques. $\mathrm{V}_{2} \mathrm{O}_{5}$ powder sample was divided into two parts. One part of the sample received the Trivedi Effect ${ }^{\circledR}$-Consciousness Energy Healing Treatment remotely by a renowned Biofield Energy Healer, Gopal Nayak was termed as a Consciousness Energy Healing Treated $\mathrm{V}_{2} \mathrm{O}_{5}$ sample, while the other part of the sample was called as a control sample. The PXRD peak intensities of the treated $\mathrm{V}_{2} \mathrm{O}_{5}$ were significantly altered in the range from $-14.29 \%$ to $54.05 \%$ compared to the control sample. Similarly, the crystallite sizes of the treated $\mathrm{V}_{2} \mathrm{O}_{5}$ were significantly altered in the range from $-13 \%$ to $111.48 \%$ compared to the control sample. However, the average crystallite size of the treated $\mathrm{V}_{2} \mathrm{O}_{5}$ (585.74) was significantly increased by $18.08 \%$ compared with the control sample (496.04) (Figure 1). The particle size values in the treated $\mathrm{V}_{2} \mathrm{O}_{5}$ were significantly decreased by $28.27 \%$ $\left(d_{10}\right), 13.6 \%\left(d_{50}\right), 7.7 \%\left(d_{90}\right)$, and $10.25 \%\{D(4,3)\}$ compared to the control sample. Thus, the specific surface area of treated $\mathrm{V}_{2} \mathrm{O}_{5}$ powder $\left(0.393 \mathrm{~m}^{2} / \mathrm{g}\right)$ was significantly increased by $64.44 \%$ compared with the control sample $\left(0.239 \mathrm{~m}^{2} / \mathrm{g}\right)$. The results concluded that the Consciousness Energy Healing Treatment might have generated a new polymorphic form of $\mathrm{V}_{2} \mathrm{O}_{5}$ which would improve the solubility, appearance due to larger crystallite/particle size and reduced surface area compared to the control sample. The treated $\mathrm{V}_{2} \mathrm{O}_{5}$ would also be useful for the industrial applications, i.e., bolometers and microbolometer arrays for thermal imaging, ethanol sensor, redox batteries for energy storage, etc.
\end{abstract}

Keywords: Vanadium pentoxide; Consciousness energy healing treatment; The Trivedi effect ${ }^{\circledR}$; PXRD; Particle size

\section{Introduction}

Vanadium pentoxide $\left(\mathrm{V}_{2} \mathrm{O}_{5}\right)$ is an inorganic compound with high oxidation state. $\mathrm{V}_{2} \mathrm{O}_{5}$ is used for the production of an alloy of iron and vanadium (ferrovanadium), sulfuric acid, phthalic anhydride, and maleic anhydride. It is also used as a detector material in bolometers and microbolometer arrays for thermal imaging, ethanol sensor, and redox batteries for energy storage [1-3]. $\mathrm{V}_{2} \mathrm{O}_{5}$ is very toxic to humans, which forms vanadate ion $\left(\mathrm{VO}_{3}^{-4}\right)$ by hydrolysis of $\mathrm{V}_{2} \mathrm{O}_{5}$ at higher $\mathrm{pH}$, which appears to inhibit the enzymes that process phosphate $\left(\mathrm{PO}_{4}{ }^{3-}\right)$ [4].

The physical and chemical properties of a substance play a critical role in manufacturing and other industrial applications. It was experimentally proved that the Biofield Energy Healing Treatment (Consciousness Energy Healing Treatment; the Trivedi Effect ${ }^{\circledR}$ ) has a substantial impact on the physicochemical properties of many substances [5-7]. The Trivedi Effect $^{\circledR}$ is a natural and the only scientifically proven phenomenon in which a skilled person can harness this intelligent energy from the Universe and can transfer it anywhere on the planet via the possible mediation of neutrinos [7]. The "Biofield" is a unique energy field which exists surrounding the every living organism's body known as Biofield Energy, which is infinite, para-dimensional electromagnetic field. Biofield based Energy Healing Therapies have been reported to have significant outcomes against various disease conditions [8]. The National Institutes of Health/National Center for Complementary and Alternative Medicine (NIH/ NCCAM) recommend and included the Energy therapy under Complementary and Alternative Medicine (CAM) category that has been accepted by the most of the U.S. population with several advantages $[9,10]$. Many scientific experiments were conducted to prove the impact of 
the Trivedi Effect ${ }^{\circledR}$-Consciousness Energy Healing Treatment on the non-living and living object(s). The Consciousness Energy Healing Treatment was proved with significant outcome in field of organic chemistry $[11,12]$, material science $[13,14]$, nutraceuticals $[15,16]$, pharmaceutical sciences $[17,18]$, cell biology $[19,20]$, microbiology $[21,22]$, and agriculture science $[23,24]$. Therefore, this study was designed to determine the impact of the Trivedi Effect ${ }^{\circledR}$ Consciousness Energy Healing Treatment on the physicochemical properties of $\mathrm{V}_{2} \mathrm{O}_{5}$ powder using powder X-ray diffraction (PXRD) and particle size analysis (PSA).

\section{Materials and Methods}

\section{Chemicals and reagents}

$\mathrm{V}_{2} \mathrm{O}_{5}$ powder was purchased from Sigma-Aldrich, India and other chemicals used during the experiments also purchased in India.

\section{Consciousness energy healing treatment strategies}

The test sample $\mathrm{V}_{2} \mathrm{O}_{5}$ powder was divided into two parts. One part of $\mathrm{V}_{2} \mathrm{O}_{5}$ powder sample was received the Consciousness Energy Healing Treatment (the Trivedi Effect ${ }^{\circledR}$ ) remotely under standard laboratory conditions for 3 minutes by the renowned Biofield Energy Healer, Gopal Nayak, India, known as the treated $\mathrm{V}_{2} \mathrm{O}_{5}$ sample. The other part of $\mathrm{V}_{2} \mathrm{O}_{5}$ powder sample was treated with a "sham" healer considered as a control sample. The "sham" healer did not have any idea about the Consciousness Energy Healing Treatment. After the treatment, both the $\mathrm{V}_{2} \mathrm{O}_{5}$ samples were kept in sealed conditions and characterized using PXRD and PSA analytical techniques.

\section{Characterization}

The PXRD analysis of $\mathrm{V}_{2} \mathrm{O}_{5}$ powder samples was performed with the help of Rigaku MiniFlex-II Desktop X-ray diffractometer (Japan) $[25,26]$. The average size of crystallites was calculated from PXRD data using the Scherrer's formula (1)

$$
\mathrm{G}=\mathrm{k} \lambda / \beta \cos \theta
$$

Where $\mathrm{G}$ is the crystallite size in $\mathrm{nm}$, $\mathrm{k}$ is the equipment constant, $\lambda$ is the radiation wavelength, $\beta$ is the full-width at half maximum, and $\theta$ is the Bragg angle [27]. Similarly, the PSA of $\mathrm{V}_{2} \mathrm{O}_{5}$ was performed with the help of Malvern Mastersizer 2000 (UK) using the wet method $[28,29]$. The $\%$ change in peak intensity, crystallite size, particle size, and specific surface area of the Consciousness Energy Healing Treated $\mathrm{V}_{2} \mathrm{O}_{5}$ sample was calculated compared with the control sample using the following equation 2 :

$\%$ change $=[($ Treated-Control $) /$ Control $] \times 100(2)$

\section{Results and Discussion}

\section{Powder X-ray diffraction (PXRD) analysis}
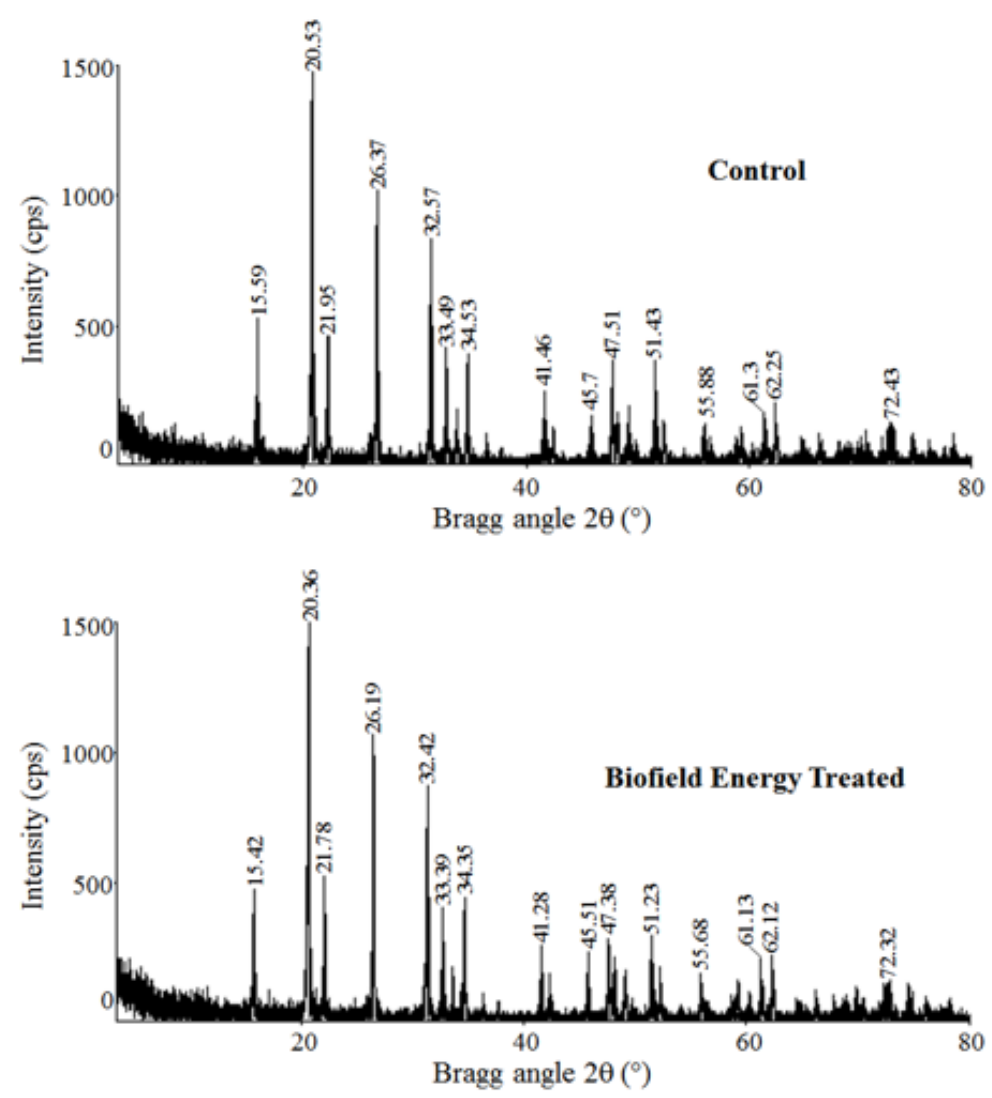

Figure 1: PXRD diffractograms of the control and consciousness energy healing treated $\mathrm{V}_{2} \mathrm{O}_{5}$. 
The diffractograms of the control and Consciousness Energy Treated $\mathrm{V}_{2} \mathrm{O}_{5}$ powder showed sharp and intense peaks (Figure 1) indicated that both the samples were crystalline in nature. The PXRD diffractograms of the control and Consciousness Energy Healing Treated $\mathrm{V}_{2} \mathrm{O}_{5}$ samples showed the highest peak intensity at $2 \theta$ equal to $20.53^{\circ}$ and $20.36^{\circ}$, respectively (Table $1 \& 2$ ). Overall the peak intensities of the Consciousness Energy Healing Treated $\mathrm{V}_{2} \mathrm{O}_{5}$ were significantly altered in the range from $-14.29 \%$ to $54.05 \%$ compared to the control sample (Table 1, entry 1-15). Similarly, the crystallite sizes of the treated $\mathrm{V}_{2} \mathrm{O}_{5}$ were significantly altered in the range from $-13 \%$ to $111.48 \%$ compared to the control sample. However, the average crystallite size of the treated $\mathrm{V}_{2} \mathrm{O}_{5}$ (585.74) was significantly increased by $18.08 \%$ compared with the control sample (496.04). The alteration in the crystallite sizes and peak intensities significantly of the Consciousness Energy Healing Treated $\mathrm{V}_{2} \mathrm{O}_{5}$ might have altered the crystal morphology compared with the control sample. If the crystal morphology change, the peak intensity of each diffraction face on the crystalline compound also changes [30], and alterations in the XRD pattern provide the proof of polymorphic transitions [31,32]. From the experimental results, it can be assumed that a new polymorphic form of $\mathrm{V}_{2} \mathrm{O}_{5}$ has been produced due to Trivedi Effect ${ }^{\circledR}$ via the mediation of neutrino oscillation [7]. The new polymorphic forms of a crystal have a substantial impact on the physicochemical properties which are different from the original one [33,34]. Thus, the Consciousness Energy Healing Treated $\mathrm{V}_{2} \mathrm{O}_{5}$ would be better for industrial use.

Table 1: PXRD data for the control and consciousness energy healing treated $\mathrm{V}_{2} \mathrm{O}_{5}$.

\begin{tabular}{|c|c|c|c|c|c|c|c|c|}
\hline \multirow{2}{*}{ Entry No. } & \multicolumn{2}{|c|}{ Bragg angle $\left({ }^{\circ} 2 \theta\right)$} & \multicolumn{3}{|c|}{ Peak Intensity (\%) } & \multicolumn{3}{|c|}{ Crystallite size (G, nm) } \\
\hline & Control & Treated & Control & Treated & $\%$ Change & Control & Treated & $\%$ Change \\
\hline 1 & 15.59 & 15.42 & 53.8 & 51.9 & -3.53 & 486 & 504 & 0.61 \\
\hline 2 & 20.53 & 20.36 & 199 & 209 & 5.03 & 427 & 507 & -9.38 \\
\hline 3 & 21.95 & 21.78 & 56.7 & 57 & 0.53 & 423 & 499 & -13 \\
\hline 4 & 26.37 & 26.19 & 124 & 119 & -4.03 & 523 & 595 & 3.48 \\
\hline 5 & 32.57 & 32.42 & 50.6 & 45.4 & -10.28 & 592 & 476 & 0.87 \\
\hline 6 & 33.49 & 33.39 & 12.3 & 11.9 & -3.25 & 581 & 753 & 14.22 \\
\hline 7 & 34.53 & 34.35 & 47.6 & 46.9 & -1.47 & 650 & 568 & 19.28 \\
\hline 8 & 41.46 & 41.28 & 27 & 34.6 & 28.15 & 524 & 567 & 3.93 \\
\hline 9 & 45.7 & 45.51 & 22.7 & 22.6 & -0.44 & 592 & 581 & 32.79 \\
\hline 10 & 47.51 & 47.38 & 42 & 36 & -14.29 & 769 & 656 & 62.63 \\
\hline 11 & 51.43 & 51.23 & 40.2 & 43 & 6.97 & 674 & 670 & 19.9 \\
\hline 12 & 55.88 & 55.68 & 11.1 & 17.1 & 54.05 & 731 & 658 & 20.45 \\
\hline 13 & 61.3 & 61.13 & 20.3 & 22.3 & 9.85 & 615 & 554 & 7.53 \\
\hline 14 & 62.25 & 62.12 & 18.9 & 23.9 & 26.46 & 747 & 654 & 2.36 \\
\hline 15 & 72.43 & 72.32 & 10 & 14.2 & 42 & 775 & 467 & 111.48 \\
\hline 16 & & & ge crystalli & & & 496.04 & 585.74 & 18.08 \\
\hline
\end{tabular}

Table 2: Particle size distribution of the control and consciousness energy healing treated $\mathrm{V}_{2} \mathrm{O}_{5}$.

\begin{tabular}{|c|c|c|c|c|c|}
\hline Parameter & $\mathbf{d}_{\mathbf{1 0}}(\boldsymbol{\mu m})$ & $\mathbf{d}_{\mathbf{5 0}}(\boldsymbol{\mu m})$ & $\mathbf{d}_{\mathbf{9 0}}(\boldsymbol{\mu m})$ & $\mathbf{D}(\mathbf{4}, \mathbf{3})(\boldsymbol{\mu m})$ & 83.5 \\
\hline Control & 15.57 & 49.76 & 207.39 & 74.94 & 0.239 \\
\hline $\begin{array}{c}\text { Biofield Energy } \\
\text { Treated }\end{array}$ & 11.17 & 42.99 & 191.42 & -10.25 & 0.393 \\
\hline Percent change (\%) & -28.27 & -13.6 & -7.7 & $\mathbf{g})$ \\
\hline
\end{tabular}

$d_{10}, d_{50}$, and $d_{90}$ : particle diameter corresponding to $10 \%, 50 \%$, and $90 \%$ of the cumulative distribution, D (4,3): the average mass-volume diameter, and SSA: the specific surface area.

\section{Particle Size Analysis (PSA)}

The particle size distribution analysis of both the control and Consciousness Energy Healing Treated $\mathrm{V}_{2} \mathrm{O}_{5}$ powder was performed and the data are presented in Table 2. The particle size values in the Consciousness Energy Healing Treated $\mathrm{V}_{2} \mathrm{O}_{5}$ were significantly decreased at $\mathrm{d}_{10}, \mathrm{~d}_{50}, \mathrm{~d}_{90}$, and $\mathrm{D}(4,3)$ by $28.27 \%, 13.6 \%, 7.7 \%$, and $10.25 \%$, respectively compared to the control sample. Thus, the specific surface area of Consciousness Energy Healing Treated
$\mathrm{V}_{2} \mathrm{O}_{5}$ powder $\left(0.393 \mathrm{~m}^{2} / \mathrm{g}\right)$ was significantly increased by $64.44 \%$ compared with the control sample $\left(0.239 \mathrm{~m}^{2} / \mathrm{g}\right)$. The results suggested that the Consciousness Energy Healing Treatment might be acting like a quantum of energy for cracking the larger particle into the smaller one and hence increased the surface area of $\mathrm{V}_{2} \mathrm{O}_{5}$ powder compared to the control sample. Incising the surface area might increase the solubility and dissolution rate [35] of the Consciousness Energy Healing Treated $\mathrm{V}_{2} \mathrm{O}_{5}$ and would be better for the industrial applications. 


\section{Conclusion}

The Trivedi Effect ${ }^{\circledR}$-Consciousness Energy Healing Treatment showed significant effects on the peak intensities, crystallite size, particle size, surface area, and thermal properties of the $\mathrm{V}_{2} \mathrm{O}_{5}$ powder. The PXRD peak intensities of the Consciousness Energy Healing Treated $\mathrm{V}_{2} \mathrm{O}_{5}$ were significantly altered in the range from $-14.29 \%$ to $54.05 \%$ compared to the control sample. Similarly, the crystallite sizes of the Consciousness Energy Healing Treated $\mathrm{V}_{2} \mathrm{O}_{5}$ were significantly altered in the range from $-13 \%$ to $111.48 \%$ compared to the control sample. However, the average crystallite size of the Consciousness Energy Healing Treated $\mathrm{V}_{2} \mathrm{O}_{5}$ was significantly increased by $18.08 \%$ compared with the control sample. The particle size values in the Consciousness Energy Healing Treated $\mathrm{V}_{2} \mathrm{O}_{5}$ were significantly decreased by $28.27 \%\left(\mathrm{~d}_{10}\right)$ $13.6 \%\left(d_{50}\right), 7.7 \%\left(d_{90}\right)$, and $10.25 \%\{\mathrm{D}(4,3)\}$ compared to the control sample. Thus, the specific surface area of Consciousness Energy Healing Treated $\mathrm{V}_{2} \mathrm{O}_{5}$ powder was significantly increased by 64.44\% compared with the control sample. The results concluded that the Consciousness Energy Healing Treatment might have generated a new polymorphic form of $\mathrm{V}_{2} \mathrm{O}_{5}$ which would improve the solubility, appearance due to larger crystallite/particle size and reduced surface area compared to the control sample. The treated $\mathrm{V}_{2} \mathrm{O}_{5}$ would also be useful for the industrial applications, i.e., bolometers and microbolometer arrays for thermal imaging, ethanol sensor, redox batteries for energy storage, etc.

\section{Acknowledgement}

The authors are grateful to Central Leather Research Institute, SIPRA Lab. Ltd., Trivedi Science, Trivedi Global, Inc., Trivedi Testimonials, and Trivedi Master Wellness for their assistance and support during this work.

\section{References}

1. https://en.wikipedia.org/wiki/Vanadium(V)_oxide. Retrieved 05 March 2018.

2. Norman NG, Alan E (1984) Chemistry of the Elements. Oxford: Pergamon Press, UK. pp. 1140-1144.

3. Bauer G, Güther V, Hess H, Otto A, Roidl O, et al. (2005) Vanadium and Vanadium Compounds. Ullmann's Encyclopedia of Industrial Chemistry, Wiley-VCH, Weinheim, Germany.

4. Trivedi MK, Tallapragada RM (2008) A transcendental to changing metal powder characteristics. Metal Powder Report 63(9): 22-28.

5. Trivedi MK, Tallapragada RM (2009) Effect of super consciousness external energy on the atomic, crystalline and powder characterisitics of carbon allotrope powders. Materials Research Innovations 13: 473-480.

6. Trivedi MK, Patil S, Tallapragada RM (2013) Effect of biofield treatment on the physical and thermal characteristics of Silicon, Tin and Lead powders. J Material Sci Eng 2: 125.

7. Trivedi MK, Mohan TRR (2016) Biofield energy signals, energy transmission and neutrinos. American Journal of Modern Physics 5(6): 172-176.

8. Rubik B, Muehsam D, Hammerschlag R, Jain S (2015) Biofield science and healing: history, terminology, and concepts. Glob Adv Health Med 4: 8-14.
9. Barnes PM, Bloom B, Nahin RL (2008) Complementary and alternative medicine use among adults and children: United States, 2007. Natl Health Stat Report 12: 1-23.

10. Koithan M (2009) Introducing complementary and alternative therapies. J Nurse Pract 5(1): 18-20.

11. Trivedi MK, Branton A, Trivedi D, Nayak G, Bairwa K, et al. (2015) Physical, thermal and spectroscopical characterization of biofield treated triphenylmethane: An impact of biofield treatment. J Chromatogr Sep Tech 6: 292.

12. Trivedi MK, Branton A, Trivedi D, Nayak G, Bairwa K, et al. (2015) Fourier transform infrared and ultraviolet-visible spectroscopic characterization of ammonium acetate and ammonium chloride: An impact of biofield treatment. Mod Chem appl 3: 163.

13. Trivedi MK, Nayak G, Patil S, Tallapragada RM, Latiyal O, et al. (2015) Studies of the atomic and crystalline characteristics of ceramic oxide nano powders after bio field treatment. Ind Eng Manage 4: 161.

14. Trivedi MK, Patil S, Nayak G, Jana S, Latiyal O (2015) Influence of biofield treatment on physical, structural and spectral properties of boron nitride. J Material Sci Eng 4: 181.

15. Trivedi MK, Tallapragada RM, Branton A, Trivedi D, Nayak G, et al. (2015) Evaluation of biofield energy treatment on physical and thermal characteristics of selenium powder. Journal of Food and Nutrition Sciences 3: 223-228.

16. Trivedi MK, Tallapragada RM, Branton A, Trivedi D, Nayak G, et al. (2015) Potential impact of biofield treatment on atomic and physical characteristics of magnesium. Vitam Miner 3: 129.

17. Trivedi MK, Branton A, Trivedi D, Nayak G, Bairwa K, et al. (2015) Spectroscopic characterization of disulfiram and nicotinic acid after biofield treatment. J Anal Bioanal Tech 6: 265.

18. Trivedi MK, Branton A, Trivedi D, Shettigar H, Bairwa K, et al. (2015) Fourier transform infrared and ultraviolet-visible spectroscopic characterization of biofield treated salicylic acid and sparfloxacin. Nat Prod Chem Res 3: 186.

19. Trivedi MK, Patil S, Shettigar H, Gangwar M, Jana S (2015) In Vitro evaluation of biofield treatment on cancer biomarkers involved in endometrial and prostate cancer cell lines. J Cancer Sci Ther 7: 253-257.

20. Trivedi MK, Patil S, Shettigar H, Mondal SC, Jana S (2015) The potential impact of biofield treatment on human brain tumor cells: a time-lapse video microscopy. J Integr Oncol 4: 141.

21. Trivedi MK, Patil S, Shettigar H, Mondal SC, Jana S (2015) An impact of biofield treatment: Antimycobacterial susceptibility potential using BACTEC 460/MGIT-TB system. Mycobact Dis 5: 189.

22. Trivedi MK, Branton A, Trivedi D, Nayak G, Mondal SC, et al. (2015) Antibiogram, biochemical reactions and biotyping of biofield treated Providencia rettgeri. American Journal of Health Research 3(6): 344-351.

23. Trivedi MK, Branton A, Trivedi D, Nayak G, Gangwar M, et al. (2015) Agronomic characteristics, growth analysis, and yield response of biofield treated mustard, cowpea, horse gram, and groundnuts. International Journal of Genetics and Genomics 3: 74-80.

24. Trivedi MK, Branton A, Trivedi D, Nayak G, Mondal SC, et al. (2015) Evaluation of plant growth, yield and yield attributes of biofield energy treated mustard (Brassica juncea) and chick pea (Cicer arietinum) seeds. Agriculture, Forestry and Fisheries 4: 291-295.

25. Desktop X-ray Diffractometer “MiniFlex”. The Rigaku Journal 14: 29-36, 1997.

26. Zhang T, Paluch K, Scalabrino G, Frankish N, Healy AM, et al. (2015) Molecular structure studies of (1S,2S)-2-benzyl-2,3-dihydro-2(1Hinden-2-yl)-1H-inden-1-ol. J Mol Struct 1083: 286-299. 
27. Langford JI, Wilson AJC (1978) Scherrer after sixty years: A survey and some new results in the determination of crystallite size. J Appl Cryst 11: $102-113$.

28. Trivedi MK, Sethi KK, Panda P, Jana S (2017) A comprehensive physicochemical, thermal, and spectroscopic characterization of zinc (II) chloride using X-ray diffraction, particle size distribution, differential scanning calorimetry, thermogravimetric analysis/differential thermogravimetric analysis, ultraviolet-visible, and Fourier transforminfrared spectroscopy. International Journal of Pharmaceutical Investigation 7(1): 33-40.

29. Trivedi MK, Sethi KK, Panda P, Jana S (2017) Physicochemical, thermal and spectroscopic characterization of sodium selenate using XRD, PSD, DSC, TGA/DTG, UV-vis, and FT-IR. Marmara Pharmaceutical Journal 21(2): 311-318.

30. Inoue M, Hirasawa I (2013) The relationship between crystal morphology and XRD peak intensity on $\mathrm{CaSO}_{4} \cdot 2 \mathrm{H}_{2} \mathrm{O}$. Journal of Crystal Growth 380: 169-175.
31. Raza K, Kumar P, Ratan S, Malik R, Arora S (2014) Polymorphism: The phenomenon affecting the performance of drugs. SOJ Pharm Pharm Sci 1: 10 .

32. Brittain HG (2009) Polymorphism in pharmaceutical solids in drugs and pharmaceutical sciences, volume $192,2^{\text {nd }}$ Edn, Informa Healthcare USA, Inc., New York.

33. Censi R, Martino PD (2015) Polymorph impact on the bioavailability and stability of poorly soluble drugs. Molecules 20(10): 18759-18776.

34. Blagden N, de Matas M, Gavan PT, York P (2007) Crystal engineering of active pharmaceutical ingredients to improve solubility and dissolution rates. Adv Drug Deliv Rev 59(7): 617-630.

35. Chereson R (2009) Bioavailability, bioequivalence, and drug selection. In: Makoid CM, Vuchetich PJ, Banakar UV (Eds.), Basic pharmacokinetics ( $1^{\text {st }}$ Edn) Pharmaceutical Press, London. 